\title{
DETERMINATION OF TOTAL ORGANIC PHOSPHORUS IN SAMPLES OF MINERAL SOILS
}

\author{
Armi KaILA \\ University of Helsinki, Department of Agricultural Chemistry
}

Received July, 24, 1962

The determination of the total content of organic phosphorus in soil samples still seems to form a problem which is not yet quite satisfactorily resolved. This is due to the fact that we do not know what, actually, we are trying to estimate: at present only about one half of the compounds forming the organic phosphorus complex in soils is identified. We must resort to indirect methods in which the difference between the corresponding contents of "total" and inorganic phosphorus is taken to represent the organic phosphorus content of the soil sample. It is likely that the composition of the organic phosphorus complex varies, at least to some extent, in various kind of soils. Also, there may be marked differences in the mechanism and intensity of the retention of phosphorus compounds by soil constituents. Therefore, it is easy to understand that results obtained by various methods do not always agree, and that the authors have different opinion on the superiority of the methods. In lack of any absolute standard, each of us usually likes to consider his or her own procedure the most reliable one.

\section{Basis for comparison of methods}

Two types of indirect methods are employed for the estimation of the total content of organic phosphorus in soil samples: the mextraction methods" and the wignition methods». In the former type, the organic phosphorus is determined as the difference in the contents of total and inorganic phosphorus in soil extracts usually obtained by successive treatments with acid and alkali. In the latter type, the organic phosphorus is supposed to correspond to the increase in the extractable amount of inorganic phosphorus owing to the destruction of organic matter in the soil sample. 
Since it is likely that most of the extraction procedures do not completely bring the organic phosphorus compounds into solution, that method is generally considered the most reliable which gives the highest values for organic phosphorus. The other important source of error, the possibility of hydrolysis of some organic phosphorus compounds during the treatment, also corroborates the supposition that the superiority of an extraction method is connected with the production of maximum results. Yet, this is a valid criterion only in the case that there are no factors which may disturb the measurement of the total and inorganic phosphorus in the extracts. A too high content of silica or sulphates in the digested solutions may lead to an erroneous increase in the values of total phosphorus $(5,6)$. On the other hand, in the connection with the discolouring of the alkaline extract for the determination of the inorganic phosphorus, some adsorption of phosphate by carbon or precipitating organic matter may occur, owing to which too low values are obtained for inorganic phosphorus. Enough attention is not always paid to these possibilities.

The reliability of the results obtained by the ignition methods depends on the completeness of the decomposition of organic phosphorus during the ignition. The mineralized organic phosphorus must be completely removed by the extraction, and no changes in the solubility of the initial inorganic phosphorus may occur during the destruction of the organic matter in the soil sample. It is not easy to estimate to what extent the negative error arising from incomplete decomposition and extraction of organic phosphorus will compensate the positive error brought about by the increase in the solubility of soil inorganic phosphorus. LEGG and BLACK (9), using the extraction method of MEнta et al. (10) as a standard, found that when ignition is performed at temperatures higher than $300^{\circ} \mathrm{C}$ the positive error will be higher than the negative one. Although it is obvious that more information is needed of the possible level of these errors, it may be concluded that when ignition methods are in question, the procedure which gives the highest results is not always the most reliable one.

When the different methods for the estimation of soil organic phosphorus are compared, the conclusions are usually drawn without paying sufficient attention to the fact that none of the procedures can give results of high precision. Even though the extractions were performed as correctly as possible, the treatment of the extracts before the determination of their phosphorus content may cause errors. Also the inaccuracy in the measuring of the phosphate must be taken into consideration. In routine work, the errors in the measured concentrations may be as high as 0.005 or even $0.01 \mathrm{mg} . / \mathrm{l}$. of P. The final results expressed e.g. as $\mathrm{mg} . / \mathrm{kg}$. are obtained by multiplying the measured phosphorus values by factors from 1000 to 5000 , and by taking the difference between the data for total and inorganic phosphorus. Thus, it is obvious that the content of organic phosphorus cannot be reported at a greater accuracy than at $10-20 \mathrm{ppm}$ of soil, and some times even this may be a far too precise estimation. The fact has been emphasized that there must consistently exist differences higher than $20 \mathrm{ppm}$ of organic phosphorus between the respective values of various methods, before any of the methods can be considered superior to the other ones (8). Anderson (1) also finds that organic phosphorus differences of $2 \mathrm{mg}$. of $\mathrm{P}$ per $100 \mathrm{~g}$. of soil, or less, have little or no significance. 
In order to get the organic phosphorus completely removed from the soil sample, a fairly vigorous treatment is often necessary. In the procedure proposed by MEнTA et al. (10) the soil is successively extracted with concentrated $\mathrm{HCl}$ at temperatures up to $70^{\circ} \mathrm{C}, 0.5 \mathrm{~N} \mathrm{NaOH}$ at room temperature, and $0.5 \mathrm{~N} \mathrm{NaOH}$ at $90^{\circ} \mathrm{C}$. Yet, the more drastic the treatment is, the higher the risk of a partial hydrolysis of the organic phosphorus compounds will be. According to the data reported by ANDERson (1) the hydrolysis of organic phosphates added to the soil sample tended to be higher during the extraction by the Menta method than during the mild extraction procedure of Saunders and Williams (12). Anderson recommended the use of a mild alkaline extraction before the acid extraction of the Menta method in order to obviate the hydrolysis of inositol hexaphosphate, glycerophosphate, glucose-1phosphate, and nucleic acids. In this way the hydrolysis of added organic phosphates was largely prevented, and the native organic phosphorus extracted from an acid soil was slightly increased while the modification did not alter the result for a calcareous soil.

This kind of procedure, with four different extractions, is however, fairly laborious and not well suited for routine work. It may be more advantageous to use a method with fewer manipulations. The author has adopted a simple extraction procedure for the determination of organic phosphorus in samples of mineral soils (7). The procedure proposed for the determination of organic phosphorus in peat soils (8) was modified by omitting the second treatment with alkali at $90^{\circ} \mathrm{C}$. This was done because it was found that the addition of an extraction with hot alkali to the successive treatments with acid and cold alkali did not usually significantly increase the values for organic phosphorus in samples of mineral soils. Also, instead of 1-gm. samples 2-gm. samples were used in order to reduce the relative errors connected with the weighing and other treatments. The method was the following:

A 2-gm. sample of soil is treated with $50 \mathrm{ml}$. of $4 \mathrm{~N} \mathrm{H}_{2} \mathrm{SO}_{4}$ in a 100 -ml. Erlenmeyer flask for 18 hours at room temperature with occasional stirring during the first hour. After filtration and washing with distilled water to give a leachate of $200 \mathrm{ml}$. the filter paper with soil is transferred to a $300-\mathrm{ml}$. Erlenmeyer flask, $200 \mathrm{ml}$. of $0.5 \mathrm{~N} \mathrm{NaOH}$ is added, and the suspension is left to stand over night with occasional stiring during the first two hours. The thoroughly mixed suspension is poured into a high glass, and on the following day the clear supernatant extract is analysed. For the determination of inorganic phosphorus, equal amounts of the acid extract and the alkaline extract are mixed, and the dark organic matter precipitated is removed by filtering through paper or by centrifuging. The destruction of organic matter for the determination of total phosphorus is performed by wet combustion with the aid of a mixture containing two parts of $70 \%$ perchloric acid and one part of concentrated $\mathrm{H}_{2} \mathrm{SO}_{4}$. The difference between the contents of total and inorganic phosphorus is taken to represent the organic phosphorus content.

This procedure was compared with the method of MEHTA et al. (10) on a material consisting of 345 samples of Finnish soils. The analyses were performed as routine 
work, in series of 24 samples. The duplicate determinations were run in different series. The author's modification of the molybdenum blue method (6) was used for the determination of phosphate.

The material analysed contained samples of sand, fine sand, loam, silt, clay loam, sandy loam, sandy clay, silty clay, and heavy clay. 226 of the samples were collected from the surface layers down to $20 \mathrm{~cm}$., 119 samples originated from deeper layers, mostly from the depths between 20 and $60 \mathrm{~cm}$. Both cultivated soils and virgin soils were represented.

For the characterization of the material the following data of the $\mathrm{pH}$-values measured in $0.02 \mathrm{~N} \mathrm{CaCl}_{2}$ in the ratio of 1 to 2.5 , the content of organic $\mathrm{C}$, and the content of total $\mathrm{P}$ determined by the sodium carbonate fusion are recorded:

\begin{tabular}{clccc} 
& & range & mean & $\mathrm{s}$ \\
$\mathrm{pH}$ & surface samples & $3.5-7.3$ & 5.2 & 0.6 \\
& deeper layers & $3.3-7.5$ & 5.5 & 0.8 \\
$\mathrm{C} \%$ & surface samples & $0.9-10.9$ & 3.9 & 1.6 \\
& deeper layers & $0.1-2.4$ & 0.7 & 0.6 \\
Tot. P ppm surface samples & $380-1760$ & 950 & 270 \\
\multicolumn{2}{c}{ deeper layers } & $100-1720$ & 630 & 230
\end{tabular}

It was found that, obviously, the Menta method is slightly more vigorous than the author's procedure: the amount of total phosphorus extracted by the former was, on the average, $11 \mathrm{ppm}$ higher than the quantities removed by the latter from these soil samples. The application of Student's t-test shows that this difference is highly significant. On the other hand, also the mean of the inorganic phosphorus content in the extracts of the Mehta method is higher than that of the simpler procedure. As a result from this, it was found that the mean of the differences between the respective values for the organic phosphorus content was exactly $0 \mathrm{ppm}$.

Table 1. The distribution of the samples according to the difference between their org. P. content by the methods of MентA et al. and KaILA

\begin{tabular}{|c|c|c|c|c|c|c|c|c|c|c|c|c|c|}
\hline Difference org. P. ppm. & -50 & -40 & -30 & -20 & -10 & 0 & 10 & 20 & 30 & 40 & 50 & 60 & 70 \\
\hline Surface layer & 1 & 9 & 12 & 26 & 36 & 67 & 25 & 21 & 17 & 5 & 5 & 2 & 1 \\
\hline Deeper layers & & 2 & 9 & 14 & 19 & 42 & 25 & 6 & & 2 & & & \\
\hline All samples & 1 & 11 & 21 & 40 & 55 & 109 & 50 & 27 & 17 & 7 & 4 & 2 & 1 \\
\hline
\end{tabular}

To illustrate the results in more detail, the distribution of the differences in the organic phosphorus values obtained by the method of Menta et al. and by the author's procedure are listed in Table 1. It may be seen that for 214 samples, or about 62 per cent of all the samples, the both methods gave results which do not differ from each other more than $10 \mathrm{ppm}$. Since it is likely that a difference of 20 
ppm. will not be significant when the results of this kind of estimations are compared, it may be said that the number of samples for which the both methods were equally effective is 281 or about 81 per cent of all the samples analyzed. In about 9 per cent of the cases the Mehta method appears to have given higher results than did the author's procedure, while the opposite is true for an equal part of the material or for 10 per cent of the samples.

If the 73 samples are examined for which the results obtained by the Mehta method were at least $20 \mathrm{ppm}$. lower than those given by the less vigorous procedure, it may be found that the respective amounts of total phosphorus extracted by these methods were, on the average, equal. The average inorganic phosphorus content in the extracts of the Mehta method, on the other hand, was $30 \mathrm{ppm}$. higher than the corresponding values obtained by the author's procedure. The examination of the 58 samples for which the Mehta method gave results, at least $20 \mathrm{ppm}$. higher than the other method shows that the former procedure removed from the samples, on the average, $30 \mathrm{ppm}$, more total phosphorus, but that no difference existed in the respective average value for inorganic phosphorus. In the latter cases, the Mehta method obviously was more effective in the extraction of the organic phosphorus. In the former cases the opposite may be true, although it is more likely that the higher content of inorganic phosphorus in the extracts may be attributed to the hydrolysis of a part of the organic phosphorus extracted.

No significant difference could be found between these two groups of samples in their $\mathrm{pH}$-values, or contents of organic carbon, clay, or phosphorus. There tended to be more samples from the deeper layers and from the virgin soils in the group for which the results given by the Menta method were lower than those obtained by the less vigorous procedure. Yet, it cannot be concluded that, in general, the origin of the sample would be decisive.

The present results according to which the method by MEнTA and co-workers cannot be considered superior to the simple extraction procedure proposed do not disagree with the few comparative studies of various methods published. BLESSE (2) in comparing several methods on 25 soil samples found that the highest respective quantities of organic phosphorus were obtained for 13 soils by the method of WRENSHALl and Dyer (14) and for 5 soils by the method of Mehta and co-workers. On the average, the latter gave results which were 96 per cent of those by the former one. ANDERSON (1) got virtually the same values for organic phosphorus in two samples by the method of MeHTA and the fairly mild extraction procedure by SAUNDERS and Williams (12). According to more recent results (4), the Mehta method gave lower results on acid soils, probably owing to a partial hydrolysis of organic phosphorus compounds. On the calcareous soils tested the Menta method gave higher values than the mild procedure.

It also seems doubtful whether the data presented by MентA and co-workers justify their claim that values obtained by their procedure were higher than those by other methods. E.g. the differences between the respective contents of organic phosphorus obtained by their method and the method of Wrenshall and Dyer (14) for the seven samples analyzed were: 


$$
-6,-5,5,11,19,33 \text {, and } 46 \mathrm{ppm} \text {. }
$$

A conventional application of Student's t-test shows that, statistically, there is a significant difference between the results of the both methods. Yet, conclusions drawn on the basis of a larger material would have been more convinging, particularly, since the effect of the analyst seems to have been marked. In the same paper the respective results obtained by two different analysts using the method of PEARson (11) differed from each other by about $60 \mathrm{ppm}$ for one sample, and for an other sample the first analyst obtained a value which was twice as high as that found by the second analyst. It may be of interest to pay attention to the fact that of the two samples for which the values given by the MEHTA method were more than $20 \mathrm{ppm}$ higher than those obtained by the method of Wrenshall and Dyer, one was a peat soil and the other a clay loam with a high $\mathrm{pH}$ value, 7.8.

On the basis of the present material, there seems to be no reason to use the vigorous method of MEHTA and co-workers for the estimation of organic phosphorus in samples of Finnish mineral soils, since the less laborious procedure proposed will give equal results in most of the cases. It is probable that the removal of the organic phosphorus compounds by the present method is not always complete; not even the possibility of some hydrolysis of these organic compounds is excluded. Therefore, it is likely that the results obtained by this procedure, as well those given by the Menta method, may be too low. It must be emphasized that for the estimation of total organic phosphorus in peat soils, particularly in virgin peat soils, an extraction with hot alkali must be included.

\section{Ignition method and extraction method}

Provided the destruction of organic matter and the extraction of phosphorus are effective enough, the ignition methods usually tend to give somewhat higher values for the organic phosphorus than do the extraction methods $(8,9,12)$. However, the variation in the differences between the respective results of these two types of methods may be marked, and it has not yet been found out which factors will play the most important role in this regard. Mainly the possible changes in the solubility of inorganic phosphorus owing to the ignition has been emphasized.

The author has employed for the determination of organic phosphorus a simple ignition method in which a 2-gm. sample of soil is heated for one hour at $600^{\circ} \mathrm{C}$, and then it and a fresh 2-gm. sample are extracted for two hours with $200 \mathrm{ml}$. of $0.2 \mathrm{~N} \mathrm{H}_{2} \mathrm{SO}_{4}$. This ignition procedure was adopted, since it was found that $0.2 \mathrm{~N}$ acid gave practically equal results as did stronger acid (8), but it dissolves markedly less iron. Thus it is possible to determine the phosphate concentration of the extracts without special treatments. Also the phosphate concentration of the extracts is not usually so high that extra dilutions were needed.

This ignition procedure was compared with the author's extraction method on a somewhat larger material than that used for the comparison of the two extraction methods. It contained 250 samples of surface layers and 120 samples of deeper layers. 
The distribution of the samples in various classes according to the differences between the respective values of the ignition and the extraction method are recorded in Table 2. It may be seen that for 136 samples or for 37 per cent of all the material the difference between the results given by these two methods was not more than $20 \mathrm{ppm}$. The corresponding figures for the surface samples only are 67 and 27 per

Table 2. The distribution of the samples according to the difference between their organic P content by the ignition method and the extraction method

\begin{tabular}{l|rrrrrrrrrrrrrrrrrrr}
\hline Difference org. P. pp.m. & $-30-20-10$ & 0 & 10 & 20 & 30 & 40 & 50 & 60 & 70 & 80 & 90 & 100 & 110 & 120 & 130 \\
\hline \multirow{3}{*}{$\begin{array}{l}\text { Surface layers } \\
\text { Deeper layers }\end{array}$} & & 2 & 5 & 12 & 24 & 24 & 29 & 33 & 36 & 16 & 25 & 13 & 16 & 4 & 2 & 5 & 4 \\
All samples & 3 & 3 & 8 & 22 & 23 & 13 & 13 & 9 & 10 & 5 & 7 & 2 & 2 & & & \\
\hline
\end{tabular}

cent. For 28 per cent of the samples the ignition method gave values which were more than $50 \mathrm{ppm}$. higher than those obtained by the extraction procedure. The highest difference is $130 \mathrm{ppm}$. On the average, the organic phosphorus content found by the ignition method for the 250 samples of surface soils was $46 \mathrm{ppm}$. higher than the values given by the extraction method. The corresponding average difference for the 120 samples of the deeper layers was $21 \mathrm{ppm}$. It may be mentioned that the average content of organic phosphorus in the surface layers was about $340 \mathrm{ppm}$, and in the samples from deeper layers about $80 \mathrm{ppm}$.

In order to study whether the level of the difference could be connected with any characteristics of the soil, the total correlation coefficients were calculated between the difference and the following factors: $\mathrm{pH}$-value, the content of clay, aluminium and iron soluble in Tamm's acid oxalate, the indicator of the phosphate retention capacity determined by the method of TERÄSVUORI (13), and the fraction of $\mathrm{NaOH}$-soluble inorganic phosphorus determined by the method of CHANG and JACKSON (3).

The only statistically significant coefficient was found for the surface samples between the clay content and the difference: $r=0.290^{* *}$. For the samples from the deeper layers the correlation coefficient between the difference and the indicator of the phosphate retention capacity was $\mathrm{r}=0.378^{* * *}$, and between the difference and content of $\mathrm{NaOH}$-soluble inorganic phosphorus $\mathrm{r}=0.290^{* *}$.

The difference between the respective results of the ignition and extraction method tends to increase with the increase in the content of organic phosphorus, although the connection is not close. The total correlation coefficient is $\mathrm{r}=0.482^{* * *}$ for the samples of surface soils. There is no correlation for the samples from deeper layers.

The samples for which the ignition method gave values more than $80 \mathrm{ppm}$. higher than the organic phosphorus content found by the extraction method tended to have a slightly higher content of total and organic phosphorus, clay, organic 
matter and aluminium soluble in Tamm's acid oxalate than did the other part of the material. On the other hand, those few samples of surface soils which gave higher phosphorus content by the extraction method were fairly poor in phosphorus, finer fractions and soluble aluminium. The samples of the deeper layers which yielded somewhat lower values by the ignition method did not markedly differ from the other samples. The reason for the lower results by the ignition procedure may be attributed to the increase in the phosphate retention owing to the ignition. This could be proved for four soils tested by estimating the sorption of added phosphate from the $0.2 \mathrm{~N} \mathrm{H}_{2} \mathrm{SO}_{4}$ solution by ignited and unignited samples.

These observations do not indicate that the difference between the respective results obtained by the ignition and extraction method would depend on only one or two characteristics of the soil. It is likely that this difference arises from several factors which may even exert a partially contradictory effect. Usually, some of the factors will lead to too low values of the extraction method, and other factors may cause an opposite error in the results of the ignition method.

\section{Discussion}

The results of the present study do not settle the problem of the estimation of the total organic phosphorus content of soil samples. On the contrary, they show that it is likely that the extraction method by Menta and co-workers which in the present literature is often considered to be the standard method is not superior to less vigorous and less laborious extraction procedures on mineral soils. Obviously, the higher liability to hydrolysis during the treatments of the Menta method corresponds to the possible less effective removal of organic phosphorus from the samples by the milder methods.

It seems to be possible to prevent or decrease the hydrolysis of organic phosphorus compounds by some pre-extraction, but this will make the procedure more laborious and less suitable for routine work. Since most of the ignition methods usually give higher values for organic phosphorus than the extraction methods, they may be recommendable. The studies performed at the Macaulay Institute, Scotland, strongly confirm the validity of the ignition methods for the estimation of organic phosphorus in Scottish soils $(1,4,12)$.

On the basis of the present results, the ignition method adopted may give more accurate results than the simple extraction procedure employed which is likely to yield slightly too low values. Yet, also the ignition method is liable to errors, it may even give too low results owing to an increase in the retention of inorganic phosphorus during the ignition. Therefore, the author recommends for the present the estimation of the organic phosphorus as an average of the results obtained by the ignition method and the extraction method. A higher reliability will compensate the extra work. If the ignition value would be lower than the extraction value, it is likely that the former is incorrect. 
In this paper some observations on the estimation of organic phosphorus in mineral soils are reported. The fact is emphasized that the accuracy of all the methods available is relatively poor. Usually, there are no reasons to pay attention to differences less than about $20 \mathrm{ppm}$. of organic P.

Analyses performed on 345 samples of Finnish mineral soils by the extraction method of Menta et. al. (10) and by a simple procedure adopted by the author (successive extractions with $4 \mathrm{~N} \mathrm{H}_{2} \mathrm{SO}_{4}$ and $0.5 \mathrm{~N} \mathrm{NaOH}$ at room temperature in the ratio of 1 to 100) gave, on the average, equal results. It seemed to be likely that the Menta method removed the organic phosphorus more completely than did the less vigorous method, but in the former the partial hydrolysis of organic phosphorus compounds tends to be higher than in the latter.

An attempt was made to find out whether the differences between the respective values for organic phosphorus obtained by an ignition method and the simple extraction method could be connected with any characteristics of the soil. No correlation or only a low correlation coefficient could be calculated between the difference in the results of these two methods and e. g. the $\mathrm{pH}$-value, the content of clay, organic carbon, aluminium and iron soluble in Tamm's acid oxalate, the indicator of the phosphate sorption capacity, or the "Fe-bound» inorganic phosphorus, respectively. The absolute difference tended to increase with an increase in the content of organic phosphorus. For the 250 samples of surface soils analyzed, the ignition method gave values which were, on the average, about $50 \mathrm{ppm}$. higher than the results obtained by the extraction procedure. The corresponding difference for the 120 samples from deeper layers was about $20 \mathrm{ppm}$ of organic $\mathrm{P}$.

The author recommends, for the present, the determination of the total soil organic phosphorus as an average of the results obtained by the ignition method and the extraction method.

\section{REFERENCES}

(1) Anderson, G. 1960. Factors affecting the estimation of phosphate esters in soil. J. Sci. Food Agric. 11: $497-503$.

(2) Blesse, F. 1955. Vergleichende Untersuchungen über einige Methoden zur Bestimmung des organisch gebundenen Phosphors im Boden. Forsch. u. Beratung H 5: 114-115.

(3) Сhang, S. C. \& Jackson, M. L. 1957. Fractionation of soil phosphorus. Soil Sci. 84: 133-144.

(4) Hance, R. J. \& Anderson, G. 1962. A comparative study of methods of estimating soil organic phosphate. J. Soil Sci. (in press).

(5) KaIlA, A. 1948. Viljelysmaan orgaanisesta fosforista. (Summary: On the organic phosphorus in cultivated soils.) Maatal. koet. julk. No 129. Helsinki.

(6) _- 1955. Studies on the colorimetric determination of phosphorus in soil extracts. Acta Agr. Fenn. 83: 25-47.

(7) - 1961. Effect of incubation and liming on the phosphorus fractions in soil. J. Sci. Agric. Soc. Finland 33: 185-193.

(8) - - \& Virtanen, O. 1955. Determination of organic phosphorus in samples of peat soils. Ibid. 27: 104-115. 
(9) LegG, J. O. \& Black, C. A. 1955. Determination of organic phosphorus in soils: II. Ignition method. Soil Sci. Soc. Amer. Proc. 19: 139-143.

(10) Mehta, N. C. \& Legg, J. O. \& Goring, C. A. I. \& Black, C. A. 1954. Determination of organic phosphorus in soils: I. Extraction method. Ibid. 18: 443-149.

(11) Pearson, R. W. 1940. Determination of organic phosphorus in soils. Ind. Eng. Chem., Anal. Ed. 12: $198-200$.

(12) Saunders, W. M. H. \& Williams, E. G. 1955. Observations on the determination of total organic phosphorus in soils. J. Soil Sci. 6: 254-267.

(13) Teräsvuori, A. 1954. Ưber die Anwendung saurer Extraktionslösungen zur Bestimmung des Phosphordüngerbedarfs des Bodens. Staatl. Landw. Versuchstätigkeit, Veröff. Nr. 141, Helsinki.

(15) Wrenshall, C. L. \& Dyer, W. J. 1939. A method for the determination of organic phosphorus in soils and soil extracts. Canad. J. Res. B. 17: 199-205.

S E L OS T U S :

\title{
KIVENNÄISMAIDEN ORGAANISEN FOSFORIN MÄÄRITTÄMISESTÅ
}

\author{
Armi Kail.A
}

Yliopiston maanviljelyskemian laitos, Helsinki

Tutkimuksessa on osoitettu laajahkon aineiston perusteella, että nykyisin miltei standardi-metodina pidetty Mентаn ja kumppaneiden (10) menetelmä antaa kivennäismaiden orgaanisen fosforin pitoisuudeksi keskimäärin samat tulokset kuin tekijän käyttämä yksinkertainen uuttomenetelmä. Ilmeisesti orgaanisen fosforin suurempi hydrolysoituminen Mehtan menetelmän käsittelyissä vastaa vähemmän voimakkaan menetelmän uuttamatta jättämän orgaanisen fosforin mäăräă.

Polttometodin ja uuttometodin antamien tulosten eroa ei pystytty kytkemään selvästi mihinkään maan ominaisuuteen.

Tekijä pitää toistaiseksi luotettavimpana tapana määrittää maan orgaanisen fosforin pitoisuus polttometodin ja uuttometodin tulosten keskiarvona. 